\title{
Test-day models for South African dairy cattle for participation in international evaluations
}

\author{
B.E. Mostert ${ }^{1 \#}$, H.E. Theron ${ }^{1}$, F.H.J. Kanfer ${ }^{2}$ and E. van Marle-Köster ${ }^{3}$ \\ ${ }^{1}$ ARC-LBD, Private Bag X2, Irene 0062, South Africa \\ ${ }^{2}$ Department of Statistics, University of Pretoria, Pretoria 0002, South Africa \\ ${ }^{3 .}$ Department of Animal and Wildlife Sciences, University of Pretoria, Pretoria 0002, South Africa
}

\begin{abstract}
Variance components and breeding values of production traits and somatic cell score of South African Guernsey, Ayrshire, Holstein and Jersey breeds have been estimated using a multi-lactation repeatability test-day model, including tests of the first three lactations as repeated measures and fitting the permanent environmental effect across lactations. Multitrait evaluations were done for the production traits (milk, butterfat and protein) and single trait evaluations for somatic cell score. Heritability estimates were comparable with yield and somatic cell score estimates obtained by test-day models from other countries (17-24\% for milk yield; $10-13 \%$ for butterfat yield; $14-19 \%$ for protein yield and 6-8\% for somatic cell score). Proofs of qualifying sires were sent to the International Bull Evaluation Service (INTERBULL) for participation in the March 2005 test runs. Genetic correlations between South Africa and other participating countries, estimated by INTERBULL, compared well with those amongst the other participating countries. Trend validation tests were successful using this methodology for all traits and breeds except for somatic cell score of the Guernsey breed, due to insufficient data for this trait. South Africa can now participate in routine INTERBULL evaluations to obtain Multiple Across Country Evaluation (MACE) breeding values, using this methodology.
\end{abstract}

Keywords: Ayrshire, Guernsey, Holstein, Jersey, production traits, repeatability model, somatic cell score

\#Corresponding author. E-mail: bernice@arc.agric.za

\section{Introduction}

Estimates of genetic and phenotypic parameters and the various components of variances and covariances therein are necessary elements for the estimation of breeding values. These estimates need to be relevant for each population and the actual situation where they are to be used (Danell, 1982). In recent years, interest in test-day records has increased among dairy geneticists and among members of the dairy cattle breeding industry (Swalve, 2000), i.e. the inclusion of test-day records as they are in genetic evaluations instead of using lactation records that are calculated from them (Swalve, 1998). A test-day model for genetic evaluation can account for factors that are specific to each test-day, such as management groups within a herd on a test-day, day of the year (including weather conditions), and, for each cow, days in milk, pregnancy status, medical treatments and number of times milked on the test-day. Many of these factors change for a cow from one test-day to the next, and would be difficult to model for 305-day yields (Jamrozik et al., 1997).

Test-day models have been implemented for South African Holstein and Jersey cows, including testdays of the first three lactations as repeated measures and fitting the permanent environmental effect within lactation (Mostert et al., 2004a; b). The Jersey evaluation was submitted to the March 2004 International Bull Evaluation Service (INTERBULL) test run. INTERBULL is the sub-committee of the International Committee for Animal Recording (ICAR) who is responsible for global genetic evaluations. Genetic correlations amongst countries participating in INTERBULL evaluations are estimated by INTERBULL during these test runs, for subsequent estimation of the Multiple Across Country Evaluations (MACE) breeding values in international routine evaluations. Data used by INTERBULL for estimation of genetic correlations are de-regressed breeding values for all artificial insemination bulls that have daughters in at least 10 herds in the country of origin. Correlations are estimated using the software package developed at the Holstein Association USA by Klei \& Weigel (1998). Correlations are estimated simultaneously for all countries, except for Holstein where subsets of countries are considered. 
Although South Africa's test-day methodology was accepted after the March 2004 test run, concern was expressed regarding low correlations of South Africa with countries sharing a reasonable number of common sires, especially for protein yield (e.g. as low as $58 \%$ for milk, $30 \%$ for butterfat and $19 \%$ for protein yield) (Freddy Fikse, 2004: Personal communication, INTERBULL Centre Director, e-mail: Freddy.Fikse@hgen.slu.se). As the permanent environmental effect accounts for environmental similarities between test-day records of the same cow, ranking of sires might be influenced when permanent environmental variance is fitted across lactations opposed to only within lactation, because different sires are linked to different numbers of test-day records per daughter per lactation. If test-day records of cows are therefore not linked across lactations, ranking of sires might be influenced as the effect of ignoring environmental similarities across lactations will differ among sires. Furthermore, fitting the permanent environmental effect across lactations is done by most countries where records of different lactations are included as repeated measures. Harmonisation of South Africa's genetic methodology with those of other countries might therefore improve genetic correlations between South Africa and the other countries participating in INTERBULL evaluations. The aim of this study was therefore to investigate the effect of fitting the permanent environmental effect across lactations in the South African Test-Day Model for genetic evaluation of production traits and somatic cell score (SCS) for the Ayrshire, Guernsey, Holstein and Jersey breed populations, with regards to variance components estimated and genetic correlations obtained with countries genetically linked to South Africa, for successful participation in international genetic evaluations.

\section{Materials and Methods}

For the Ayrshire, Guernsey, Holstein and Jersey breeds, data consisted of test-day records of somatic cell count (SCC), and milk, butterfat and protein yields for lactations $1-3$, calving from 1982 (1984 for the Guernseys) to 2004. These records were obtained from the Integrated Registration and Genetic Information System (INTERGIS) for cows participating in the South African Dairy Animal Improvement Scheme. The number of test-day records available was 418806 for the Ayrshires, 179466 for the Guernseys, 2961647 for the Jerseys and 8826442 for the Holsteins. Basic edits included deletion of records with unknown herds, unknown birth dates and calving dates, test-days recorded before five days in milk or after 305 days in milk, records of crossbred cows and age restrictions within lactations to ensure reasonable calving ages in a specific lactation (20 - 42 months for lactation 1, 30 - 54 months for lactation 2 and 40 - 66 months for lactation 3 for Holsteins and 17 - 40 months for lactation 1, 29 - 53 months for lactation 2 and $41-67$ months for lactation 3 for the other breeds). Protein yield was set to zero for records where protein percentages were greater than $6 \%$ or less than $2 \%$. The same was done with butterfat yield where butterfat percentages were higher than $9 \%$ or lower than $2 \%$. Records where test-day milk yields were higher than $70 \mathrm{~kg}$ (90 kg for Holstein) or lower than $1 \mathrm{~kg}$ (2.5 kg for Holstein) were also deleted. Lactations should fit the following requirements to be included (specifications from IRIS - the national dairy management system):

1. First test of a lactation should be within the first 63 days in milk.

2. No interval longer than 100 days between tests of a lactation was allowed.

3. Only one interval between 60 and 100 days was allowed per parity.

Lactations ending before 60 days in milk were also discarded.

Records deleted amounted to $21 \%$ for Ayrshire, $11 \%$ for Guernsey, $13 \%$ for Jersey and $16 \%$ for Holstein databases. The remaining records were used to estimate Best Linear Unbiased Prediction (BLUP) breeding values for production traits and SCS.

In order to ensure a well-linked data structure for variance component estimation, the data sets were selected according to the study of Haile-Mariam et al. (2000). Only records where both parents were known, were used. Contemporary groups were defined as Herd x Test-Date x Parity x Number of milkings/day. Only $25 \%$ of these contemporary groups of the first parity was randomly selected for the Holstein and $60 \%$ for the Jersey analyses. The records were further subjected to the following requirements:

- Cows included in the analysis should have a first parity;

- There should be daughters of at least three sires in a contemporary group (two for the Guernseys and Holsteins);

- The contemporary group should consist of at least five records (six for the Ayrshires); 
- Each sire should be represented in at least four contemporary groups (three for Jerseys, two for Holsteins);

- Each lactation was divided into 10 stages of 30 days each, except for the $10^{\text {th }}$ stage which consisted of 35 days (270-305). Only one test-day record per stage per cow was included in the analyses;

- A cow should have at least eight test-days per lactation to be selected (six for the Guernseys and Jerseys and five for the Holsteins);

- A sire should have at least six daughters in the first lactation (three for the Guernseys).

This selection was an interactive process, with the number of records available and data quality for each data set leading to certain decisions with regards to the above-mentioned requirements.

Somatic cell count (1000's/mL) was transformed to $\log (\mathrm{SCC})$ for each test-day to achieve normality. This will be referred to as SCS.

(Co)variance components were estimated using VCE4 (Groeneveld \& Garcia-Cortes, 1998) with the model as described by Mostert et al. (2004a,b) :

\begin{tabular}{|c|c|}
\hline Where & \\
\hline $\mathrm{y}_{\mathrm{ijklmn} p}$ & $\begin{aligned}= & \mathrm{p}^{\text {th }} \text { test-day milk, butterfat or protein yield of cow } \mathrm{j} \text { in lactation } \mathrm{m} \text { in herd } \mathrm{x} \\
& \text { test-date } \mathrm{x} \text { parity } \mathrm{x} \text { milkings group } \mathrm{i} \text {, of season } \mathrm{k} \text {, age class } \mathrm{l} \text { and calving } \\
& \text { interval class } \mathrm{n}\end{aligned}$ \\
\hline$\mu$ & $=$ mean yield \\
\hline HTDLM $_{\mathrm{i}}$ & $=$ fixed effect of herd $\mathrm{x}$ test-date $\mathrm{x}$ parity $\mathrm{x}$ number of milkings group \\
\hline$A_{j}$ & $=$ animal additive genetic effect \\
\hline $\mathrm{PE}_{\mathrm{j}}$ & $\begin{aligned}= & \text { permanent environmental (random) effect to account for common effects of } \\
& \text { environment associated with all test-day records of cow } \mathrm{j}\end{aligned}$ \\
\hline $\mathrm{S}_{\mathrm{km}}$ & $=$ fixed effect of calving season in lactation $\mathrm{m}$ \\
\hline $\mathrm{AC}_{\mathrm{lm}}$ & $=$ fixed effect of ageclass in lactation $\mathrm{m}$ \\
\hline wilmink $\left(S_{\mathrm{km}}\right)$ & $\begin{array}{l}=\text { Wilmink curve (Wilmink, 1987) modelled on days in milk within season } \mathrm{k} \\
\text { and in lactation } \mathrm{m} \text { (regression) }\end{array}$ \\
\hline $\mathrm{CI}_{\mathrm{nm}}$ & $=$ fixed effect of calving interval class in lactation $\mathrm{m}$ \\
\hline$e_{i j k l m n p}$ & $=$ random residual error \\
\hline
\end{tabular}

Two seasons were defined, April - September and October - March, while the same age classes were allocated as in the derivation of standard lactation curves by Mostert et al. (2001). Calving interval classes were allocated using standard deviation units, as follows:

Code 1: All records of Lactation 1; Code 2: All records of Lactation 2 with unknown calving intervals (no Lactation 1 records available); Code 3: All records of Lactation 2 where the calving interval was smaller than 1 standard deviation unit from the average calving interval; Code 4: All records of Lactation 2 where the calving interval was within 1 standard deviation unit from the average calving interval; Code 5: All records of Lactation 2 where the calving interval was greater than 1 standard deviation unit from the average calving interval; Code 6: All records of Lactation 3 with unknown calving intervals (no Lactation 2 records available); Code 7: All records of Lactation 3 where the calving interval was smaller than 1 standard deviation unit from the average calving interval; Code 8: All records of Lactation 3 where the calving interval was within 1 standard deviation unit from the average calving interval; Code 9: All records of Lactation 3 where the calving interval was greater than 1 standard deviation unit from the average calving interval.

As calving interval class did not have a significant influence $(\mathrm{P}<0.05)$ on SCC, it was not included in the model for SCS for variance component estimation. This model therefore assumed consecutive test-day samples to be repeated observations on the same trait and permanent environmental effects accounted for environmental similarities between different test-days, within and across lactations.

For variance component estimation pedigrees were traced back for three generations. Multitrait analyses were run for the production traits and single trait analyses for SCS for each breed. The software package, PEST (Groeneveld \& Kovac, 1990) was used to estimate breeding values, using the unselected data 
set and the same models as for variance component estimation. The pedigrees were, however, traced back as far as possible and genetic groups were incorporated to ensure that base animals enter the evaluation on the appropriate genetic level. Proofs of qualifying sires were sent to INTERBULL for participation in the March 2005 test runs.

\section{Results and Discussion}

The data structure and statistics of the selected data sets are presented in Tables 1 and 2. The average sizes of the contemporary groups involved in variance component estimation for the production traits are worth mentioning. The Guernsey data set yielded the smallest contemporary group sizes of 9.3 cows per group, in comparison with the Jersey (12.4 cows) and Holstein (13.5 cows) data sets. The Ayrshire data set had an average contemporary group size of 25.8 cows and also yielded the most test-day records per cow per lactation. In the Ayrshire population, only 13 herds (29\% of the herds participating in milk recording) consisted of more than 100 animals. Discipline of milk recording and therefore data quality led to selection of data from the larger herds for the Ayrshire population. However, these herds did account for $71 \%$ of the data and are therefore still representative of the breed.

Table 1 Data structure of the selected data sets for Ayrshire, Guernsey, Holstein and Jersey breeds. Average daughters per sire and dam are indicated, as well as (average) contemporary group sizes

\begin{tabular}{|c|c|c|c|c|c|c|}
\hline Trait & $\begin{array}{l}\text { Number of } \\
\text { cows }\end{array}$ & $\begin{array}{c}\text { Number of } \\
\text { sires } \\
\text { (Average } \\
\text { daughters/sire) }\end{array}$ & $\begin{array}{c}\text { Number of } \\
\text { dams } \\
\text { (Average } \\
\text { daughters/dam) }\end{array}$ & $\begin{array}{c}\text { Number of } \\
\text { CG } \\
\text { (Average } \\
\text { daughters/CG) }\end{array}$ & $\begin{array}{l}\text { Number of } \\
\text { herds }\end{array}$ & $\begin{array}{c}\text { Number of } \\
\text { animals in } \\
\text { pedigree }\end{array}$ \\
\hline \multicolumn{7}{|c|}{ Ayrshires } \\
\hline Production & 7042 & $\begin{array}{c}281 \\
(25.1)\end{array}$ & $\begin{array}{l}5264 \\
(1.34)\end{array}$ & $\begin{array}{l}3814 \\
(25.9)\end{array}$ & 64 & 13098 \\
\hline SCS & 3552 & $\begin{array}{c}207 \\
(17.2) \\
\end{array}$ & $\begin{array}{r}2736 \\
(1.30) \\
\end{array}$ & $\begin{array}{l}1245 \\
(32.7)\end{array}$ & & 13098 \\
\hline \multicolumn{7}{|c|}{ Guernseys } \\
\hline Production & 3042 & $\begin{array}{c}266 \\
(11.4)\end{array}$ & $\begin{array}{l}2466 \\
(1.23)\end{array}$ & $\begin{array}{l}4412 \\
(9.3)\end{array}$ & 49 & 6813 \\
\hline SCS & 2327 & $\begin{array}{c}192 \\
(12.1)\end{array}$ & $\begin{array}{l}1729 \\
(1.35)\end{array}$ & $\begin{array}{c}3310 \\
(8.2)\end{array}$ & & 6813 \\
\hline \multicolumn{7}{|c|}{ Holsteins } \\
\hline Production & 14856 & $\begin{array}{l}1565 \\
(9.5)\end{array}$ & $\begin{array}{l}11975 \\
(1.24)\end{array}$ & $\begin{array}{l}6583 \\
(13.5)\end{array}$ & 86 & 44070 \\
\hline SCS & 4135 & $\begin{array}{r}737 \\
(5.7) \\
\end{array}$ & $\begin{array}{l}3644 \\
(1.13)\end{array}$ & $\begin{array}{l}1416 \\
(15.6)\end{array}$ & & 44070 \\
\hline \multicolumn{7}{|c|}{ Jerseys } \\
\hline Production & 5264 & $\begin{array}{c}505 \\
(10.4)\end{array}$ & $\begin{array}{l}4032 \\
(1.31)\end{array}$ & $\begin{array}{l}5747 \\
(11.3)\end{array}$ & 90 & 12713 \\
\hline SCS & 2007 & $\begin{array}{l}254 \\
(7.9) \\
\end{array}$ & $\begin{array}{l}1630 \\
(1.23)\end{array}$ & $\begin{array}{c}1161 \\
(14.33)\end{array}$ & & 12713 \\
\hline
\end{tabular}

CG - contemporary group levels; SCS - somatic cell score: Range 6.91 - 16.12

As expected average production was highest for Holstein cows with regards to milk and protein yields per day (Table 2). The Ayrshires, however, produced on average more butterfat per day compared to the Holsteins, but the maximum butterfat yield per day was delivered by a Holstein cow $(3.22 \mathrm{~kg} /$ day $)$. The Holstein cows also had the highest average SCS of 11.75 and showed the most variation when compared to the other breeds, while the average SCS of the Ayrshires was lowest of all the breeds. 
Table 2 Number of test-day records per lactation, average number of test-day records per cow and general statistics of the traits of the selected data sets for Ayrshire, Guernsey, Holstein and Jersey breeds

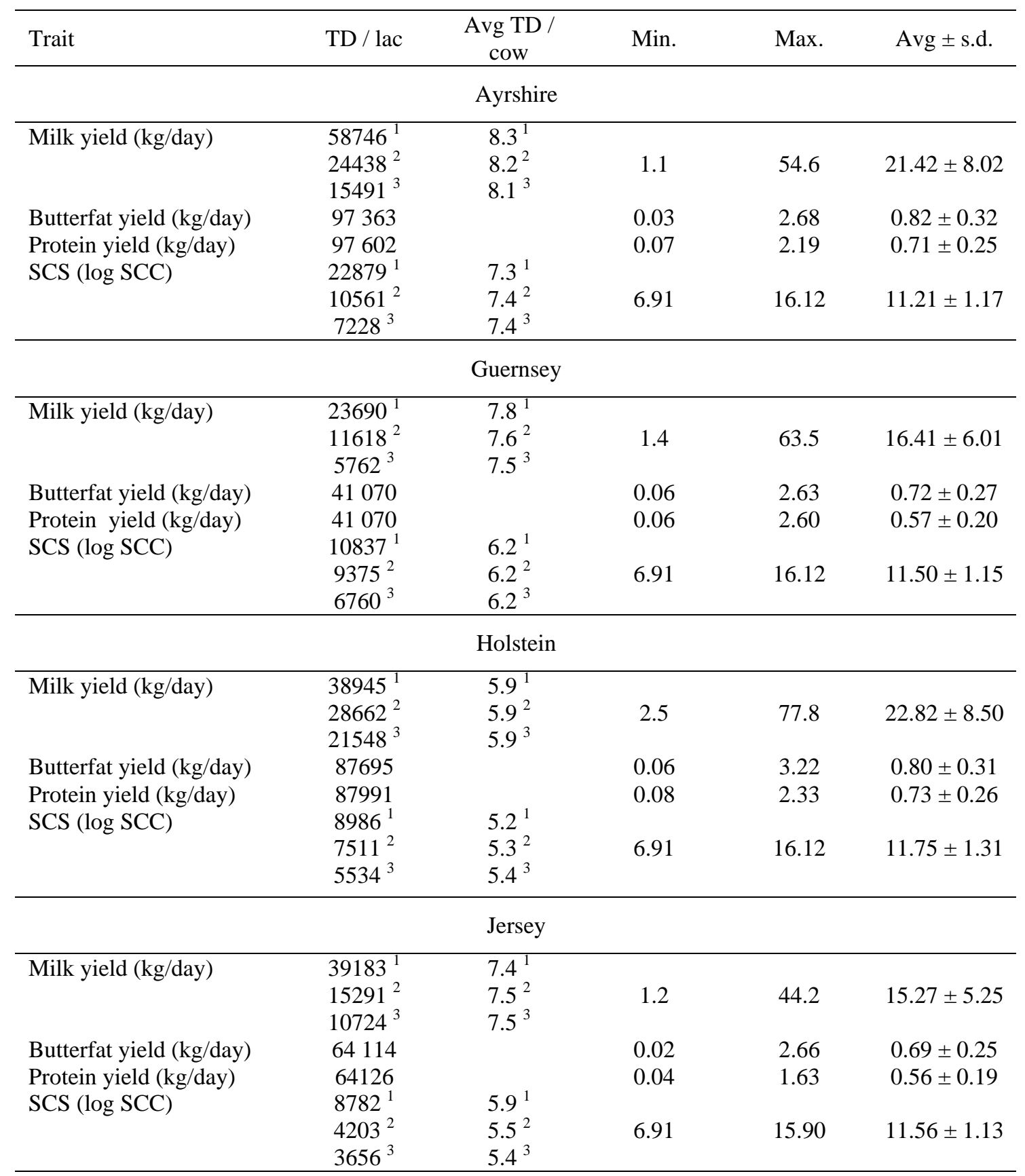

SCS - somatic cell score; log SCC - somatic cell count (1000’s/mL) transformed to logarithmic scale s.d. - standard deviation; TD / lac - number of test-day records per lactation

123 - lactations 1,2 and 3, respectively

Except for the Holstein evaluation, all multitrait analyses converged successfully. Several random selections were made on the Holstein data set and although convergence with status 1 (first derivative is zero) could not be obtained with any of the variance component estimation runs, estimates of the different runs were similar. Average estimates of the different runs are therefore presented without standard deviations for the Holsteins. Variance component ratios and genetic correlations for the different breeds are indicated in Table 3. 
Table 3 Variance component ratios and correlations ( \pm s.e.) for production traits and somatic cell score (SCS)

\begin{tabular}{|c|c|c|c|c|c|}
\hline Effect & & Milk & Butterfat & Protein & SCS \\
\hline \multicolumn{6}{|c|}{ Ayrshire } \\
\hline \multirow[t]{4}{*}{ Animal } & Milk & $0.171 \pm 0.009$ & $0.891 \pm 0.009$ & $0.894 \pm 0.007$ & \\
\hline & Butterfat & & $0.102 \pm 0.006$ & $0.917 \pm 0.007$ & \\
\hline & Protein & & & $0.149 \pm 0.008$ & \\
\hline & SCS & & & & $0.064 \pm 0.010$ \\
\hline \multirow[t]{4}{*}{ PE } & Milk & $0.245 \pm 0.007$ & $0.947 \pm 0.004$ & $0.980 \pm 0.002$ & \\
\hline & Butterfat & & $0.175 \pm 0.005$ & $0.955 \pm 0.003$ & \\
\hline & Protein & & & $0.225 \pm 0.007$ & \\
\hline & SCS & & & & $0.219 \pm 0.009$ \\
\hline \multirow[t]{4}{*}{ Residual } & Milk & $0.585 \pm 0.004$ & $0.743 \pm 0.001$ & $0.938 \pm 0.000$ & \\
\hline & Butterfat & & $0.723 \pm 0.003$ & $0.726 \pm 0.001$ & \\
\hline & Protein & & & $0.626 \pm 0.004$ & \\
\hline & SCS & & & & $0.719 \pm 0.005$ \\
\hline \multicolumn{6}{|c|}{ Guernsey } \\
\hline \multirow[t]{4}{*}{ Animal } & Milk & $0.244 \pm 0.023$ & $0.852 \pm 0.021$ & $0.919 \pm 0.010$ & \\
\hline & Butterfat & & $0.126 \pm 0.017$ & $0.895 \pm 0.017$ & \\
\hline & Protein & & & $0.188 \pm 0.021$ & \\
\hline & SCS & & & & $0.081 \pm 0.019$ \\
\hline \multirow[t]{3}{*}{ PE } & Milk & $0.314 \pm 0.021$ & $0.937 \pm 0.007$ & $0.978 \pm 0.003$ & \\
\hline & Butterfat & & $0.251 \pm 0.016$ & $0.963 \pm 0.005$ & \\
\hline & Protein & & & $0.306 \pm 0.019$ & \\
\hline \multirow[t]{5}{*}{ Residual } & SCS & & & & $0.238 \pm 0.016$ \\
\hline & Milk & $0.443 \pm 0.006$ & $0.738 \pm 0.002$ & $0.915 \pm 0.001$ & \\
\hline & Butterfat & & $0.623 \pm 0.006$ & $0.736 \pm 0.002$ & \\
\hline & Protein & & & $0.505 \pm 0.006$ & \\
\hline & SCS & & & & $0.682 \pm 0.007$ \\
\hline \multicolumn{6}{|c|}{ Holstein } \\
\hline \multirow[t]{4}{*}{ Animal } & Milk & 0.177 & 0.799 & 0.968 & \\
\hline & Butterfat & & 0.105 & 0.866 & \\
\hline & Protein & & & 0.136 & \\
\hline & SCS & & & & $0.062 \pm 0.013$ \\
\hline \multirow[t]{4}{*}{ PE } & Milk & 0.382 & 0.879 & 0.848 & \\
\hline & Butterfat & & 0.263 & 0.894 & \\
\hline & Protein & & & 0.364 & \\
\hline & SCS & & & & $0.304 \pm 0.013$ \\
\hline \multirow[t]{4}{*}{ Residual } & Milk & 0.441 & 0.662 & 0.926 & \\
\hline & Butterfat & & 0.632 & 0.677 & \\
\hline & Protein & & & 0.500 & \\
\hline & SCS & & & & $0.634 \pm 0.006$ \\
\hline \multirow{5}{*}{ Animal } & & Jer & & & \\
\hline & Milk & $0.175 \pm 0.013$ & $0.779 \pm 0.023$ & $0.898 \pm 0.010$ & \\
\hline & Butterfat & & $0.103 \pm 0.009$ & $0.882 \pm 0.014$ & \\
\hline & Protein & & & $0.155 \pm 0.012$ & \\
\hline & SCS & & & & $0.063 \pm 0.020$ \\
\hline \multirow[t]{4}{*}{$\mathrm{PE}$} & Milk & $0.304 \pm 0.012$ & $0.886 \pm 0.008$ & $0.952 \pm 0.003$ & \\
\hline & Butterfat & & $0.193 \pm 0.008$ & $0.932 \pm 0.006$ & \\
\hline & Protein & & & $0.259 \pm 0.011$ & \\
\hline & SCS & & & & $0.206 \pm 0.018$ \\
\hline \multirow[t]{4}{*}{ Residual } & Milk & $0.521 \pm 0.004$ & $0.723 \pm 0.001$ & $0.918 \pm 0.000$ & \\
\hline & Butterfat & & $0.703 \pm 0.004$ & $0.708 \pm 0.001$ & \\
\hline & Protein & & & $0.586 \pm 0.004$ & \\
\hline & SCS & & & & $0.731 \pm 0.007$ \\
\hline
\end{tabular}

PE - permanent environment; SCS range - 6.91 to 16.12 
Heritability estimates for the animal effect of the Guernsey breed were higher for all traits compared to the other breeds, i.e. $24 \%$ for milk, $13 \%$ for butterfat and $19 \%$ for protein yield, as well as $8 \%$ for SCS. Estimates for the other breeds were all in the range of: $17 \%$ for milk, $10.5 \%$ for butterfat, $15 \%$ for protein yield and 6\% for SCS. Danell (1982) found that heritability estimates of test-day yields were either the same or slightly lower than those of 305-day yields. Reents et al. (1995b) published heritability estimates averaging $26 \%$ for milk, $21 \%$ for butterfat and $23 \%$ for protein yields over three lactations, using fixed regression test-day models, treating the different lactations as different traits. Lidauer et al. (2003) reported heritability estimates of $26 \%$ for milk, $16 \%$ for protein and $17 \%$ for butterfat yields for first lactation Finnish dairy cattle using a multitrait repeatability test-day model, vs. $43 \%$ for milk, $29 \%$ for butterfat and $29 \%$ for protein yields, respectively on the same data set, using a multitrait lactation model. Pösö et al. (1996) also stated that heritability estimates for test-day milk yield tend to be generally low and distinctly lower than that of 305-day yields. Similar conclusions were drawn by Serrano et al. (2003) who also confirmed that low heritabilities were estimated with repeatability test-day animal models in sheep breeds. Heritability estimates obtained from this study were therefore on the lower range of test-day model estimates reported in the literature, but more comparable with these estimates than those obtained when fitting permanent environmental effects within lactation (Mostert et al., 2004b).

Reents et al. (1995a) concluded from various studies that the heritability for SCS ranges from $10-15 \%$ and in 1996, Mrode \& Swanson published a weighted average of $0.11 \pm 0.04$, based on different measures of first-lactation SCS from several studies. However, Reents et al. (1995b) published heritability for SCS averaging 9.7\% over three lactations for Canadian Holstein cows, using fixed regression test-day models, treating different lactations as different traits. De Haas et al. (2003) reported heritability estimates of 7-8\% for average SCS score of Dutch Friesian cows, and Mrode \& Swanson (2003) reported that the heritability of individual test-days for SCS averaged 7\% using a random regression test-day model. In contrast to these findings, estimates as high as 19\% (Pösö \& Mäntysaari, 1996) and 23\% (Luttinen \& Juga, 1997) have been reported. Mrode \& Swanson (2003) concluded that heritability from random regression models were higher than estimates from a repeatability model, using lactation averages regarding SCS. Heritability estimates for SCS from this study were again on the lower range of estimates reported in the literature, but also more in agreement to these estimates than those obtained when fitting permanent environmental effects within lactation (Mostert et al., 2004a).

As can be expected from a repeatability model, permanent environmental effects accounted for a large proportion of the phenotypic variation, with the Holstein breed allocating the most for all traits and the Ayrshire breed the least for the production traits to permanent environment. For SCS the Jersey breed yielded the smallest estimate for permanent environmental effect of all the breeds. Permanent environmental variance of the production traits for the South African breeds was 1.25 (protein yield of the Guernsey breed) to 2.68 (protein yield for the Holstein breed) times higher than the genetic variance. For SCS permanent environmental variance was even higher, ranging from 2.95 (Guernsey breed) to 4.86 (Holstein breed) times the genetic variance. Da et al. (1992) found permanent environmental variance of SCS to be two times higher than the genetic variance for Holsteins. Reents et al. (1995b) published permanent environmental variances being on average over three lactations 1.6 times higher than genetic variance for production traits, and 4.3 times higher for SCS for Ontario Holstein cows, using fixed regression test-day models. Serrano et al. (2003) reported permanent environmental variance to be four times higher than the genetic variance for SCS of Manchega ewes. According to Serrano et al. (2003) high permanent environmental variance relative to the genetic variance indicates some degree of confounding, which may be due to the lack of pedigree information and insufficient repeated measures per animal. This might explain why permanent environmental variance for SCS of all the breeds is much higher than the genetic variance, since records for SCC has only been captured on the INTERGIS since 1996, compared to 1988/1989 for the production traits, yielding more than a generation less historical data for SCS evaluations. Druet et al. (2003) and Mrode \& Swanson (2003) also reported a large influence of permanent environmental effects, especially in the early stage of lactation, when using random regression test-day models.

Residual variance for production traits was highest in the Ayrshire and Jersey breeds for SCS, with the Guernsey and Holstein analyses producing around 10\% lower estimates for production traits. It is interesting to note that the residual variation associated with butterfat yield is much larger for all the breeds, compared to that of milk and protein yields. This is probably due to butterfat yield being more sensitive to nutritional 
practices (Shirley et al., 1998; Socha \& Johnson, 1998; Pennington, 2005). Residual variances from random regression test-day models reported in the literature are smaller than the permanent environmental variance (Misztal et al., 2000; Druet et al., 2003; De Roos et al., 2004), which is in contrast with this study, where the residual variance was greater than genetic and permanent environmental variances for all traits and all breeds. This, however, can be attributed to the modelling of genetic and non-genetic variance covariance structures between any pair of test-day observations along the course of the lactation by random regression models (Lidauer et al., 2003), whereas for test-day repeatability models the random genetic animal and permanent environmental effects are modelled as constants for each day in milk (Jensen, 2001). Because random regression models allow for a more comprehensive description of animals' genotype (Lidauer et al., 2003), associated residual effects should be smaller compared to that of fixed regression test-day models. Reents et al. (1995a) also reported residual variances that are greater than genetic and permanent environmental variances for somatic cell score, using fixed regression test-day models and treating different lactations as different traits.

Genetic correlations between traits were lowest between milk and butterfat yields for all breeds, ranging from $0.779 \pm 0.023$ for the Jersey to $0.891 \pm 0.009$ for the Ayrshire. Except for the Ayrshire, which had a higher genetic correlation between butterfat and protein yields $(0.917 \pm 0.007)$, all breeds showed the highest correlation between milk and protein yields, ranging from $0.898 \pm 0.010$ for the Jersey to 0.968 for the Holstein. Not many references are available on genetic correlations between production traits based on test-day evaluations, as most test-day studies include different lactations as different traits and do evaluations separately for the yield traits. Pander et al. (1992) as well as Lidauer et al. (2003), however, also reported genetic correlations on different days in milk that are higher between milk and protein yields, compared to milk and butterfat yields on the same days in milk. Genetic correlations of 0.80 between milk and protein yields, 0.60 between milk and fat yields and 0.70 between butterfat and protein yields from a multitrait repeatability test-day model, were indicated by Lidauer et al. (2003).

Table 4 Number of common bulls for the production and somatic cell score (SCS) (indicated in brackets) traits and genetic correlations between South Africa and other countries participating in Multiple Across Country Evaluations (MACE) for the Ayrshire breed

\begin{tabular}{|c|c|c|c|c|c|c|}
\hline \multirow{2}{*}{ Country } & \multirow{2}{*}{\multicolumn{2}{|c|}{$\begin{array}{c}\text { Number of } \\
\text { common bulls }\end{array}$}} & \multicolumn{4}{|c|}{ Genetic correlations } \\
\hline & & & Milk yield & Butterfat yield & Protein yield & SCS \\
\hline AUS & $17(10)$ & & 0.81 & 0.76 & 0.80 & 0.84 \\
\hline CAN & $45(32)$ & & 0.88 & 0.86 & 0.86 & 0.89 \\
\hline DEU & $1(1)$ & & 0.86 & 0.86 & 0.86 & 0.90 \\
\hline DNK & $0(0)$ & & 0.86 & 0.86 & 0.86 & 0.88 \\
\hline EST & $0(0)$ & & 0.90 & 0.90 & 0.90 & 0.92 \\
\hline FIN & $4(1)$ & & 0.89 & 0.89 & 0.89 & 0.90 \\
\hline GBR & $12(11)$ & & 0.86 & 0.86 & 0.86 & 0.90 \\
\hline NOR & $0(-)$ & & 0.90 & 0.90 & 0.91 & - \\
\hline NZL & $18(12)$ & & 0.77 & 0.76 & 0.76 & 0.80 \\
\hline SWE & $11(8)$ & & 0.87 & 0.87 & 0.87 & 0.91 \\
\hline USA & $23(15)$ & & 0.86 & 0.86 & 0.86 & 0.90 \\
\hline \multicolumn{2}{|c|}{ AUS - Australia } & \multicolumn{2}{|c|}{ DNK - Denmark } & GBR - Great Britain & \multicolumn{2}{|c|}{ NOR - Norway } \\
\hline $\mathrm{BEL}-\mathrm{Be}$ & & \multirow{2}{*}{\multicolumn{2}{|c|}{$\begin{array}{l}\text { DNR - Danish Red \& White } \\
\text { ESP - Spain }\end{array}$}} & HUN - Hungary & \multicolumn{2}{|c|}{ NZL - New Zealand } \\
\hline \multicolumn{2}{|c|}{ CAN - Canada } & & & \multirow{2}{*}{\multicolumn{2}{|c|}{$\begin{array}{l}\text { IRL - Ireland } \\
\text { ISR - Israel }\end{array}$}} & POL - Poland \\
\hline \multirow{2}{*}{\multicolumn{2}{|c|}{$\begin{array}{l}\text { CHE - Swiss Black \& White } \\
\text { CHR - Swiss Red Holstein }\end{array}$}} & \multicolumn{2}{|c|}{ EST - Estonia } & & & SVN - Slovenia \\
\hline & & \multicolumn{2}{|c|}{ FIN - Finland } & \multicolumn{2}{|c|}{ ITA - Italy } & SWE - Sweden \\
\hline \multicolumn{2}{|c|}{ CZE - Czech Republic } & \multicolumn{2}{|c|}{ FRA - France } & \multicolumn{2}{|c|}{ JPN - Japan } & States of \\
\hline \multicolumn{2}{|c|}{ DEU - Germany } & \multicolumn{2}{|c|}{ FRR - French Pie Rouge } & \multicolumn{2}{|c|}{ NLD - Netherlands } & \\
\hline
\end{tabular}


The correlations between permanent environmental effects showed more or less the same tendency as the genetic correlations, with highest correlations between milk and protein yields, ranging from $0.952 \pm$ 0.003 for the Jersey breed to $0.980 \pm 0.002$ for the Ayrshire breed and lowest correlations between milk and butterfat yields, ranging from $0.886 \pm 0.008$ for the Jersey breed to $0.947 \pm 0.004$ for the Ayrshire breed. Although the permanent environmental ratios were highest for the Holstein breed, correlations between the traits for these effects were lower and also in a different order compared to the other breeds. For the Holstein breed the correlations between permanent environmental effects ranged from 0.848 between milk and protein yields, to 0.894 between butterfat and protein yields.

In Tables 4-7 genetic correlations between South Africa and other countries participating in INTERBULL for the Ayrshire, Guernsey, Holstein and Jersey breeds, are presented (wwwINTERBULL.slu.se). These correlations were estimated during the March 2005 INTERBULL test runs. Eighty six Ayrshire sires (54 for SCS) from South Africa qualified for participation in the March 2005 INTERBULL test run. South Africa contributed the least sires and Sweden the most sires (2508) to this test run. Most common sires were shared with Canada and no sires with Denmark, Estonia and Norway. The lowest correlations for the production traits were obtained with New Zealand for butterfat and protein yields, as well as with Australia for butterfat yield (0.76), while the highest correlations were estimated for the countries having no common sires with South Africa (0.90 and 0.91). This is due to estimates being combined with those for Holstein where few or no common bulls are available for breeds other than Holstein. Genetic correlations between other countries ranged from 0.95 for milk yield between Estonia and Norway, sharing six common sires, to 0.76 between New Zealand and Canada, Finland, USA and Sweden for butterfat yield. Norway participates in the INTERBULL Udder Health evaluations with regards to clinical mastitis, but not for SCS. Genetic correlations with other countries were higher for SCS compared to those of the production traits.

Table 5 Number of common bulls and genetic correlations between South Africa and other countries participating in Multiple Across Country Evaluations (MACE) for the Guernsey breed

\begin{tabular}{lcccc}
\hline & \multirow{3}{*}{$\begin{array}{c}\text { Number of common } \\
\text { bulls }\end{array}$} & Milk yield & Butterfat yield & Protein yield \\
\cline { 3 - 5 } & & 0.78 & 0.77 & 0.77 \\
& 6 & 0.86 & 0.86 & 0.86 \\
AUS & 2 & 0.86 & 0.86 & 0.86 \\
CAN & 4 & 0.77 & 0.77 & 0.77 \\
GBR & 4 & 0.86 & 0.86 & 0.86 \\
NZL & 9 & & & \\
\hline
\end{tabular}

See Table 4 for the country codes

From Table 5 it is clear that not many Guernsey bulls are shared between South Africa and other countries participating in MACE. The Guernsey breed is, worldwide, small in numbers, with the USA contributing the most AI-sires (576) to this test run and South Africa only 40 bulls. Nevertheless, correlations between South Africa and these countries compared well with those between the rest of the participating countries, ranging from 0.76 between, amongst others, Canada and Australia for protein yield, to 0.95 between Canada and the USA for milk yield. With regards to the Guernsey breed, South Africa correlates least with New Zealand and Australia. Due to too few records being available for SCS of the Guernsey breed, South Africa does not yet participate in INTERBULL evaluations for this trait.

The Holstein breed is by far the largest breed participating in INTERBULL. A total of 27 countries participated in the March 2005 test run, with the USA contributing most sires $(20$ 128) and France contributing least (112) sires to the evaluation. For South Africa 826 sires (616 for SCS) qualified for participation. With regards to common sires, French Pie Rouge (1) and Danish Red and Whites (2) shared 
the least and the USA the most (313) with South Africa. Correlations ranged from 0.75 with Australia (butterfat and protein yields), Ireland and New Zealand (all yield traits) to 0.91 with Danish Red and White for protein yield. Genetic correlations between other countries ranged from 0.95 between Canada and Japan, Denmark and Japan and the Netherlands and Japan for milk yield to 0.75 between amongst others, New Zealand and Canada for butterfat yield. A few countries do not yet participate in INTERBULL evaluations for SCS. Genetic correlations were generally higher for SCS in comparison with those for the production traits.

Table 6 Number of common bulls for the production and somatic cell score (SCS) (indicated in brackets) traits and genetic correlations between South Africa and other countries participating in Multiple Across Country Evaluations (MACE) for the Holstein breed

\begin{tabular}{|c|c|c|c|c|c|}
\hline \multirow{2}{*}{ Country } & \multirow{2}{*}{$\begin{array}{l}\text { Number of } \\
\text { common bulls }\end{array}$} & \multicolumn{4}{|c|}{ Genetic correlations } \\
\hline & & Milk yield & Butterfat yield & Protein yield & SCS \\
\hline AUS & 164 (128) & 0.76 & 0.75 & 0.75 & 0.91 \\
\hline BEL & $84(66)$ & 0.85 & 0.85 & 0.85 & 0.94 \\
\hline CAN & 204 (172) & 0.85 & 0.85 & 0.85 & 0.91 \\
\hline CHE & $87(86)$ & 0.86 & 0.85 & 0.85 & 0.95 \\
\hline CHR & $32(28)$ & 0.86 & 0.86 & 0.86 & 0.92 \\
\hline CZE & $84(-)$ & 0.86 & 0.86 & 0.86 & - \\
\hline DEU & $201(160)$ & 0.85 & 0.85 & 0.85 & 0.90 \\
\hline DNK & $104(79)$ & 0.85 & 0.85 & 0.85 & 0.88 \\
\hline DNR & $2(1)$ & 0.90 & 0.90 & 0.91 & 0.91 \\
\hline ESP & 190 (162) & 0.85 & 0.85 & 0.85 & 0.97 \\
\hline EST & $9(8)$ & 0.89 & 0.89 & 0.89 & 0.92 \\
\hline FIN & 12 (12) & 0.87 & 0.88 & 0.88 & 0.90 \\
\hline FRA & 139 (121) & 0.85 & 0.85 & 0.85 & 0.91 \\
\hline FRR & $1(1)$ & 0.90 & 0.90 & 0.90 & 0.92 \\
\hline GBR & 229 (185) & 0.85 & 0.85 & 0.85 & 0.92 \\
\hline HUN & 143 (114) & 0.85 & 0.85 & 0.85 & 0.89 \\
\hline IRL & $123(-)$ & 0.75 & 0.75 & 0.75 & - \\
\hline ISR & $19(13)$ & 0.77 & 0.78 & 0.77 & 0.87 \\
\hline ITA & 177 (146) & 0.85 & 0.85 & 0.85 & 0.92 \\
\hline JPN & $107(94)$ & 0.85 & 0.85 & 0.85 & 0.89 \\
\hline NLD & 198 (149) & 0.85 & 0.85 & 0.85 & 0.91 \\
\hline NZL & 159 (132) & 0.75 & 0.75 & 0.75 & 0.76 \\
\hline POL & $63(-)$ & 0.86 & 0.86 & 0.86 & - \\
\hline SVN & $20(-)$ & 0.87 & 0.87 & 0.87 & - \\
\hline SWE & 95 (120) & 0.85 & 0.85 & 0.85 & 0.92 \\
\hline USA & 313 (255) & 0.85 & 0.85 & 0.85 & 0.90 \\
\hline
\end{tabular}

See Table 4 for the country codes

Germany contributed the least (47) and New Zealand the most sires (2 342) to the March 2005 Jersey test run, with 431 sires (248 sires for SCS) qualifying for South Africa (Table 7). The most common bulls were shared with the USA (136) and least with the Netherlands (20). Again, the lowest correlations were obtained with New Zealand and Australia, 0.76 for butterfat and protein yields. With all other countries and for all the traits the genetic correlation with South Africa is 0.86, except with the USA, for which it is 0.85 . Correlations between the other countries ranged from 0.95 between Canada and the USA for milk yield, to 0.74 between New Zealand and Great Britain for milk and butterfat yields. Germany and Italy do not 
participate in the INTERBULL Udder Health evaluations. Genetic correlations between South Africa and other countries are the same or higher for SCS compared to those for production traits.

Table 7 Number of common bulls for the production and somatic cell score (SCS) (indicated in brackets) traits and genetic correlations between South Africa and other countries participating in Multiple Across Country Evaluations (MACE) for the Jersey breed

\begin{tabular}{|c|c|c|c|c|c|}
\hline \multirow{2}{*}{ Country } & \multirow{2}{*}{$\begin{array}{c}\text { Number of } \\
\text { common bulls }\end{array}$} & \multicolumn{4}{|c|}{ Genetic correlations } \\
\hline & & Milk yield & Butterfat yield & Protein yield & SCS \\
\hline AUS & $91(65)$ & 0.81 & 0.76 & 0.76 & 0.85 \\
\hline CAN & $62(49)$ & 0.86 & 0.86 & 0.86 & 0.88 \\
\hline DEU & $25(-)$ & 0.86 & 0.86 & 0.86 & - \\
\hline DNK & $45(34)$ & 0.86 & 0.86 & 0.86 & 0.86 \\
\hline GBR & $51(41)$ & 0.86 & 0.86 & 0.86 & 0.87 \\
\hline ITA & $37(-)$ & 0.86 & 0.86 & 0.86 & - \\
\hline NLD & $20(13)$ & 0.86 & 0.86 & 0.86 & 0.88 \\
\hline NZL & $91(72)$ & 0.77 & 0.76 & 0.76 & 0.77 \\
\hline USA & $136(95)$ & 0.85 & 0.85 & 0.85 & 0.89 \\
\hline
\end{tabular}

See Table 4 for the country codes

For all breeds, genetic correlations between South Africa and other participating countries were in the mid-eighties to low nineties, except with New Zealand, Australia, Ireland and Israel. Although, in general, these correlations were lower than those amongst other countries, they were well within the range of 0.74 0.95, rendering compatibility with genetic methodologies of countries participating in international evaluations. The obvious lower correlations between New Zealand, Australia, Ireland and Israel with all other countries are due to grouping of countries and setting of windows by INTERBULL so that estimates fall within certain windows (INTERBULL Technical Workshop, 2004). For yield traits separate windows are maintained depending on the climate and whether or not countries predominantly have grazing systems. Two countries with similar climate and production system (grazing vs. non-grazing) are expected to be higher correlated than two countries with different climate or production systems. If estimates are higher than the maximum (or lower than the minimum) value, they are set to the maximum (or minimum) value. In addition, estimates are regressed towards a mean correlation within groups, the regression depending on the number of common bulls. Countries grouped together are therefore Australia, Ireland and New Zealand (grazing), Israel (climate) and all other countries. Windows used, are correlation between countries belonging to the same group ( $>0.80$ ), and correlation between countries belonging to different groups $(>0.75)$. Furthermore, for breeds other than Holstein, estimates are combined with genetic correlations for Holstein, in order to obtain correlations between countries sharing few or no common bulls. Genetic correlations between countries are higher for udder health traits compared to those for production traits, due to different windows being used (correlations between countries belonging to the same group: 0.85-0.98; Correlations between countries belonging to different groups: $0.75-0.98$ ). The same grouping of countries is used for production and SCS traits (INTERBULL Technical Workshop, 2004).

\section{Conclusions}

Heritability estimates were obtained for production traits and SCS that were on the lower range of literature estimates for test-day models, using a multi-lactation repeatability test-day model where the permanent environmental effect was fitted across lactations. These estimates were, however, more in agreement with literature estimates compared to estimates from the test-day models fitting the permanent environmental effect within lactation. Trend validation tests were accepted by INTERBULL during the March 2005 test runs for all the breeds and traits, except for SCS of the Guernsey breed, due to too few records available for this breed. Genetic correlations between South Africa and other participating countries, estimated by INTERBULL during the March 2005 test runs, were around 0.80, which is close to those 
amongst the other participating countries. MACE breeding values will therefore be obtained after the May 2005 INTERBULL routine run, implementing the new methodology for South Africa's Ayrshire, Guernsey, Jersey and Holstein breeds.

\section{References}

Da, Y., Grossman, M., Misztal, I. \& Wiggans, G.R., 1992. Estimation of genetic parameters for somatic cell score in Holsteins. J. Dairy Sci. 75, 2265-2271.

Danell, B., 1982. Studies on lactation yield and individual test-day yields of Swedish dairy cows. II. Estimates of genetic and phenotypic parameters. Acta Agric. Scand. 32, 82-92.

De Haas, Y., Barkema, H.W., Schukken, Y.H. \& Veerkamp, R.F., 2003. Genetic associations for pathogenspecific clinical mastitis and patterns of peaks in somatic cell count. Anim. Sci. 77, 187-195.

De Roos, A.P.W., Harbers, A.G.F. \& De Jong, G., 2004. Random herd curves in a test-day model for milk, fat, and protein production of dairy cattle in The Netherlands. J. Dairy Sci. 87, 2693-2701.

Druet, T., Jaffrézic, F., Boichard, D. \& Ducrocq, V., 2003. Modeling lactation curves and estimation of genetic parameters for first lactation test-day records of French Holstein cows. J. Dairy Sci. 86, 24802490.

Groeneveld, E. \& Garcia-Cortes, A., 1998. VCe4.0, a (co)variance component package for frequentists and Bayesians. Proc. $6^{\text {th }}$ WCGALP. 27, 455-456.

Groeneveld, E. \& Kovac, M., 1990. A generalized computing procedure for setting up and solving mixed linear models. J. Dairy Sci. 73, 513-531.

Haile-Mariam, M., Goddard, M.E. \& Bowman, P.J., 2000. Estimates of genetic parameters for daily somatic cell count of Australian dairy cattle. J. Dairy Sci. 84, 1255-1264.

INTERBULL Technical Workshop, 2004. Genetic correlation estimation procedure. January 2004. Uppsala, Sweden.

Jamrozik, J., Schaeffer, L.R. \& Dekkers, J.C.M., 1997. Genetic evaluation of dairy cattle using test-day yield and random regression model. J. Dairy Sci. 80, 1217-1226.

Jensen, J., 2001. Genetic evaluation of dairy cattle using test-day models. J. Dairy Sci. 84, 2803-2812.

Klei, B. \& Weigel, K., 1998. A method to estimate correlations among countries using data on all bulls. Proc. 1998 INTERBULL Meeting, Rotorua, New Zealand, Jan 18-19, 8-14.

Lidauer, M., Mäntysaari, E.A. \& Strandén, I., 2003. Comparison of test-day models for genetic evaluation of production traits in dairy cattle. Livest. Prod. Sci. 79, 73-86.

Luttinen, A. \& Juga, J., 1997. Genetic relationships between milk yield, somatic cell count, mastitis and leakage in Finnish dairy cattle population. In: Proc. International Workshop on Genetic Improvement of Functional Traits in Cattle: Health. Uppsala, Sweden, June, INTERBULL Bull. No. 15, 78-83.

Misztal, I., Strabel, T., Jamrozik, J., Mäntysaari, E.A. \& Meuwissen, T.H.E., 2000. Strategies for estimating the parameters needed for different test-day models. J. Dairy. Sci. 83, 1125-1134.

Mostert, B.E., Banga, C.B., Groeneveld, E. \& Kanfer, F.H.J., 2004a. Breeding value estimation for somatic cell score in South African dairy cattle. S. Afr. J. Anim. Sci. 34, 32.

Mostert, B.E., Groeneveld, E. \& Kanfer, F.H.J., 2004b. Testday models for production traits in dairy cattle. S. Afr. J. Anim. Sci. 34, 35-37.

Mostert, B.E., Theron, H.E. \& Kanfer, F.H.J., 2001. The effect of calving season and age at calving on production traits of South African dairy cattle. S. Afr. J. Anim. Sci. 31, 205-214.

Mrode, R.A. \& Swanson, G.J.T., 1996. Genetic and statistical properties of somatic cell count and its suitability as an indirect means of reducing the incidence of mastitis in dairy cattle. Anim. Breed. Abstr. 64, 847-857.

Mrode, R.A. \& Swanson, G.J.T., 2003. Estimation of genetic parameters for somatic cell count in the first three lactations using random regression. Livest. Prod. Sci. 79, 239-247.

Pander, B.L., Hill, W.G. \& Thompson, R., 1992. Genetic parameters of test-day records of British HolsteinFriesian heifers. Anim. Prod. 55, 11-21.

Pennington, J.A., 2005. Factors affecting fat percent in milk of lactating cows. Agriculture and Natural Resources. University of Arkansas Cooperative Extension Service, Little Rock.

Pösö, J. \& Mäntysaari, E.A., 1996. Relationships between clinical mastitis, somatic cell score and production for the first three lactations in Finnish Ayrshires. J. Dairy Sci. 79, 1284-1291. 
Pösö, J., Mäntysaari, E.A. \& Kettunen, A., 1996. Estimation of genetic parameters of test-day production in Finnish Ayrshire cows. Proc. 1996 INTERBULL Meeting, Veldhoven, The Netherlands, June 23-24, 45-48.

Reents, R., Dekkers, J.C.M. \& Schaeffer, L.R., 1995a. Genetic evaluation for somatic cell score with a testday model for multiple lactations. J. Dairy Sci. 78, 2858-2870.

Reents, R., Jamrozik, J., Schaeffer, L.R. \& Dekkers, J.C.M., 1995b. Estimation of genetic parameters for test-day records of somatic cell score. J. Dairy Sci. 78, 2847-2857.

Serrano, M., Pérez-Guzmán, M.D., Montoro, V. \& Jurado, J.J., 2003. Genetic analysis of somatic cell count and milk traits in Manchega ewes. Mean lactation and test-day approaches. Livest. Prod. Sci. 84, 1-10.

Shirley, J.E., Piehl, D. \& Titgemeyer, E.C., 1998. Effect of level of dietary protein on the performance of lactating dairy cows. J. Anim. Sci. 76 Suppl. 1, 251.

Socha, T. \& Johnson, A.B., 1998. Summary of trials conducted evaluating the effect of a combination of complex zinc methionine, manganese methionine, copper lysine and cobalt glucoheptonate on lactation and reproduction performance of dairy cattle. J. Anim. Sci. 76 Suppl. 1, 251.

Swalve, H.H., 1998. Use of test-day records in genetic evaluation. Proc. $6^{\text {th }}$ World Congr. Genet. Appl. Livest. Prod., Armidale, New South Wales, Australia. 23, 295-302.

Swalve, H.H., 2000. Symposium: Test-Day Models. Theoretical Basis and Computational Methods for Different Test-Day Genetic Evaluation Methods. J. Dairy Sci. 83, 1115-1124.

Wilmink, J.B.M., 1987. Adjustment of test-day milk, fat and protein yield for age season and stage of lactation. Livest. Prod. Sci. 16, 335-348. 